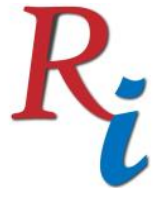

Asia Proceedings of Social Sciences

(APSS)

www.readersinsight.net/APSS

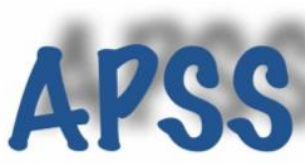

\title{
STOCK MARKET PERFORMANCE, EXCHANGE RATE VOLATILITY AND FOREIGN DIRECT INVESTMENT TO SRI LANKA \\ R P C R Rajapakse*
}

Department of Finance

University of Sri Jayewardenapura

Sri lanka

*Corrosponding author's Email: champa@sjp.ac.lk

Author's Biography

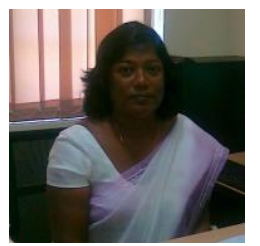

I,Dr. R P C R Rajapakse work as a senior lecturer attached to the Department of Finance, University of Sri Jayewardenepura, Sri Lanka. Completed my first degree in Business Administration at the same university and obtained masters from University of Colombo and Wakayama University, Japan under a scholarship by the Japanese Government. and I was awarded a PhD in Finance at the Ritsumeikan University, Shiga, japan. My current research interests are FDI, Tourism, Stock Market Performance and Financial Literacy.

Peer-review under responsibility of $3^{\text {rd }}$ Asia International Multidisciplanry Conference 2019 editorial board (http://www.utm.my/asia/our-team/) (C) 2019 Published by Readers Insight Publisher, lat 306 Savoy Residencia, Block 3 F11/1,44000 Islamabad. Pakistan, info@readersinsight.net This is an open access article under the CC BY-NC-ND license (http://creativecommons.org/licenses/by-nc-nd/4.0/). 


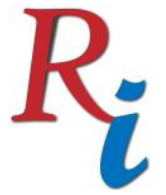

Asia Proceedings of Social Sciences

(APSS)

www.readersinsight.net/APSS

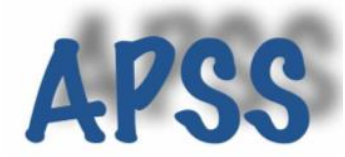

\section{Rese a r ch H i g h I igh t s}

This study intended to investigate the relationship between the performance of the stock market with FDI and exchange rate volatility. The study found that the series are cointegrated implying long term association among the variables. The estimated VECM model indicated that the coefficient for the error correction term was not significant at the five percent level. Further, the Wald test indicated that coefficients for LFDI and LNEER were also not significant. The estimated model was weak with an $r$ square of 0.163615 . Going inline with literature it was also observed that there is unidirectional causality from LMC to LFDI. The Granger causality test was neither significant for LMC and NEER nor NEER and FDI. This implies that exchange rate volatility has no influence on the performance on the stock marker the reason could be the low foreigner participation in the market. Further, FDI flows are not affected by the exchange rate volatility.

\section{Research Objectives}

Low level of savings in developing countries like Sri Lanka is a major reason for the poor rates of economic growth. Consequently, a country needs to find the capital required for economic development. Most of the countries have turned to foreign sources of financing during the transition from a centrally planned to a market economy. The dominant form of foreign capital inflows was foreign direct investments (FDI), which, due to their characteristics, may have many positive effects on the host economy (Blomström, Lipsay and Zejan, 1992; Borensztein, De Gregorio and Lee, 1998; Bosworth and Collins, 1999; Loungani and Razin, 2001; etc.). Theory regarding the characteristics of FDI emphasizes the stability, long-term motivation and flexibility of this type of capital investment, even during financial crises (Lipsey, 2001). Elwell (2012), found that foreign investors are not willing to hold assets when a currency is depreciating as that would bring down the return on their investment. In a case of domestic currency depreciation, investors refrain from holding domestic assets, including stocks. This may demotivate foreign investors in the stock market and causes share prices to drop. According to Elwell (2012), foreign investors are unwilling to hold assets in a depreciating currency as that would diminish the return on their investment. In a case of domestic currency depreciation, investors refrain from holding domestic assets, including stocks. This may demotivate foreign investors in the stock market and causes share prices to drop.Exchange rate movements are different for companies depending on their exposure to trade. Large importers suffer from depreciation of domestic currency and will have lower earnings, resulting in a drop in share prices (Krugman and Obstfeld, 2009) Therefor it's important to identify the stock market performance affected by the Foreign exchange market returns.

The aims of this study are to explain the relationship between

1. FDI and stock market performance

2. Exchange rate volatility and stock market performance

\section{Methodology}

Objectives of the study were to understand the influence of FDI and Exchange rate volatility on the stock market performance. Market capitalisation of the colombo stock exchange was taken to measure performance of the stock market. Net FDI inflows and the Nominal effective exchange rate was taken to represent the exchange rate volatility. Unit root test were done to test for stationarity of the three series, Co-integration test was carried out to test for long run association of the variables, and based on the results Vector Error Correction (VECM) model 


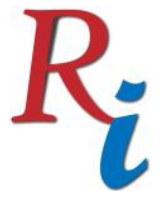

\section{Asia Proceedings of Social Sciences \\ (APSS) \\ www.readersinsight.net/APSS}

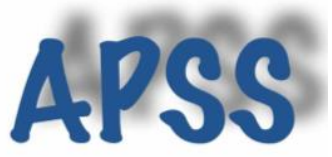

was estimated. Granger causality test was employed in this research in order to investigate the nature of causality between LMC, LFDI and LNEER. All variables were operated on econometric software EVIEWS. Quarterly time series data from 2004Q1 to 2018Q3 compiled by the Central Bank of Sri Lanka and World Bank are used and the data length was limited by the availability of data. LMC andL FDI were measured by million LKR. Exchange rate volatility was measured by LNEER

\section{Results}

This study starts with investigating whether the time series data contain unit root or not. If they do, they are non-stationary. Number of tests has been suggested to perform in order to assess whether the data series contains unit root or not. The Augmented Dickey Fuller (ADF) (Dickey \& Fuller, 1979) and Phillips-Perron (PP) (Phillips \& Perron, 1988) unit root tests are generally used by many researchers. The statistics LMC LFDI, and LNEER demonstrate stationary feature at first difference which were non stationary at levels. The co-integration test carried out in order to assess whether there is long run association among the variables LMC LFDI, and LNEER. The test results indicate that there is co-integration among the three variables which means LMC LFDI, and LNEER that there exists long run association between the variables and that in turn enabled the estimation of VECM model instead of a VAR model. The error correction term of the estimation wasn't significant and the Wald test revealed that the coefficients of LFDI and LNEER were also not significant. The Granger Causality Test reveal that there is uni directional influence by LMC on LFDI and no other causalities were observed.

\section{Findings}

The main contribution of this paper is an additional step towards the clarification of the so far rather unclear relationship between FDI and the stock market in Sri Lanka, as well as of their characteristics and determinants both in long and short run. The research proceeds from accepted theoretical assumptions, and thus represents mainly a contribution in terms of empirical research. However, the confirmation of the existence of a long term connection and the inability to prove short-term causality between the stock market and FDI in Sri Lanka can also be useful to policymakers and financial investors in the decision making process.

\section{References}

M. Blomstrom, R. Lipsey, M. Zejan (1992) What explains Developing Country Growth? NBER Working Paper Series (4132) (1992)

E. Borensztein, J.D. Gregorio, J.W. Lee How does foreign direct investment affect economic growth? Journal of International Economics, 45 (1998), pp. 115-135

Elwell, C. K. (2012). The depreciating dollar: Economic effects and policy response. Washington, DC: Congressional Research Service.

Lipsey, M., \& Wilson, D. (2001). Practical meta-analysis. Thousand Oaks, CA: Sage.

Loungani, P., and Razin, A. (2001). "How beneficial is foreign direct investment for developing countries?" Finance and Development, vol.38 (2) 